AKADEMIKA

JURNAL ILMIAH

\title{
PENGARUH TEKNIK PEMBERIAN BALIKAN DAN GAYA KOGNITIF TERHADAP HASIL BELAJAR IPA \\ (Suatu Penelitian Eksperimen di Kelas VIII SMP Negeri 2 Bongomeme)
}

\author{
Suleman \\ Program Studi PGSD Universitas Muhammadiyah Gorontalo \\ e-mail:suleman@umgo.ac.id
}

\begin{abstract}
The study aimed to find out: (1) differences in science learning outcomes between students who were taught with delayed and direct feedback giving techniques, (2) the interaction effects of feedback techniques and spatial cognitive style on science Learning outcomes, (3) differences in science learning outcomes in the group of students who have high spatial cognitive style, those who are taught using delayed and direct feedback giving techniques, (4) differences in science learning outcomes in students who have a low spatial cognitive style, are taught using delayed and reversed direct giving techniques. The method used is tretment by level with $2 \times 2$ ANAVA design. The results of this study show that the learning outcomes of science in students who are taught by the technique of giving direct natural science learning outcomes are higher than the delayed giving technique. There is an influence of the interaction between the reciprocal giving technique and the cognitive style of the students towards the learning outcomes of science. Students who have a high spatial cognitive style learned by the technique of giving direct feedback to science learning outcomes are higher than the delayed giving technique. For students who have a low spatial cognitive style, learning techniques for giving direct feedback to science learning outcomes are lower than delayed feedback techniques.
\end{abstract}

Keywords: Giving Feedback; Cognitive Style; IPA 


\begin{abstract}
Abstrak
Penelitian bertujuan untuk mengetahui: (1) perbedaan hasil belajar IPA antara peserta didik yang dibelajarkan dengan teknik pemberian balikan langsung dan balikan tertunda, (2) pengaruh interaksi teknik pemberian balikan dan gaya kognitif spasial terhadap hasil belajar IPA, (3) perbedaan hasil belajar IPA pada kelompok peserta didik yang memiliki gaya kognitif spasial tinggi, yang dibelajarkan dengan menggunakan teknik pemberian balikan langsung dan balikan tertunda, (4) perbedaan hasil belajar IPA pada peserta didik yang memiliki gaya kognitif spasial rendah, dibelajarkan dengan menggunakan teknik pemberian balikan langsung dan balikan tertunda. Metode yang digunakan adalah tretmen by leve/ dengan rancangan desain ANAVA $2 \times 2$. Hasil dari penelitian ini menunjukan hasil belajar IPA pada peserta didik yang dibelajarkan dengan teknik pemberian balikan langsung hasil belajar IPA lebih tinggi daripada teknik pemberian balikan tertunda. Terdapat pengaruh interaksi antara teknik pemberian balikan dan gaya kognitif peserta didik terhadap hasil belajar IPA. Peserta didik yang memiliki gaya kognitif spasial tinggi yang dibelajarkan dengan teknik pemberian balikan langsung hasil belajar IPA lebih tinggi daripada teknik pemberian balikan tertunda. Untuk peserta didik yang memiliki gaya kognitif spasial rendah, dibelajarkan dengan teknik pemberian balikan langsung hasil belajar IPA lebih rendah daripada teknik pemberian balikan tertunda.
\end{abstract}

Kata Kunci : Pemberian Balikan; Gaya Kognitif; IPA

\section{PENDAHULUAN}

Dalam upaya meningkatkan mutu pembelajaran, para praktisi dan pengembang teknologi pembelajaran telah banyak memperkenalkan dan menerapkan berbagai metode, pendekatan dan strategi yang disesuaikan dengan karakteristik peserta didik. Mutu pembelajaran dipengaruhi oleh kualitas proses pelaksanaan pembelajaran, juga terkait erat dengan karakteristik pembelajar atau peser tadidik. Karakteristik peserta didik yang dimaksudkan adalah antara lain kecenderungan gaya belajar peserta didik yang unik dan khas, sebagai suatu variable kondisi pembelajaran yang harus diterima sebagaimana adanya, dan tidak dapat 
dimanipulasi oleh guru atau pengembang teknologi pembelajaran.

Kualitas suatu desain dan proses pembelajaran dapat diketahui dengan caramelakukan evaluasi. Pada saat evaluasi guru juga harus diberikan penguatan yang berupa pemberian balikan. Pemberian balikan merupakan salah satu teknik penyajian dalam pembelajaran, sebagai salah satu dari tahapan proses pembelajaran, yang berhubungan dengan upaya guru untuk memantauatau mengendalikan proses pencapaian hasil pembelajaran. Teknik penyajian pemberian balikan lebih umum dikenal dengan "umpan balik" atau "feedback". Disebut "teknik" karena pada tahapan pemberian balikan, guru dapat melakukan berbagaicara yang praktis dan mudah sebagai suatu cara yang dikembangkan untuk memudahkan dirinya memperoleh informasi secepat-cepatnya terhadap usahanya melakukan proses perbaikan pelaksanaan pembelajaran.

Pemberian balikan dianggap positif, manakala ditujukan untuk menggali informasi kemampuan peserta didik atau menyampaikan perbaikan/koreksi terhadap kesalahan atau kekurangan-kekurangan yang dilakukan oleh pesertadidik. Salah satu prinsip paling mendasar dalam pemberianbalikan adalah dimensi waktu.Dalam pemberian balikan dimensi waktu ikut berpengaruh dalam malaksanakan proses penilaian hasil belajar peserta didik. Musnandar (2006) mengemukakan bahwa balikan adalah salah satu teknik untuk membuat peserta didik aktif mempelajari kembali kegagalannya dalam mengerjakan tes atau latihan.

Konsep pembejalaran IPA yang cenderung abstrak dan kompleks, menuntut kemampuan abstraksi yang tinggi dari peserta didik dalam memahami pengetahuan atau konsep yang diperolehnya selama mengikuti proses pembelajaran. kemampuan abstrak terkait dengan tingkah laku kognitif peserta didik yang disebut gaya kognitif. Gaya kognitif merupakan sikap atau kecenderungan tingkah laku yang relatif stabil pada diri peserta didik dalam menerima, memahami, mengingat, berpikir dan menyelesaikan masalah.

Salah satu dimensi gaya kognitif adalah gaya kognitif spasial. Gaya kognitif spasial terkait dengan kemampuan melihat dan mengamati dunia visual spasial secara akurat, dan kemampuan bertindak atas persepsi tersebut. Gaya kognitif spasial dimaksud bila diperhatikan dalam 


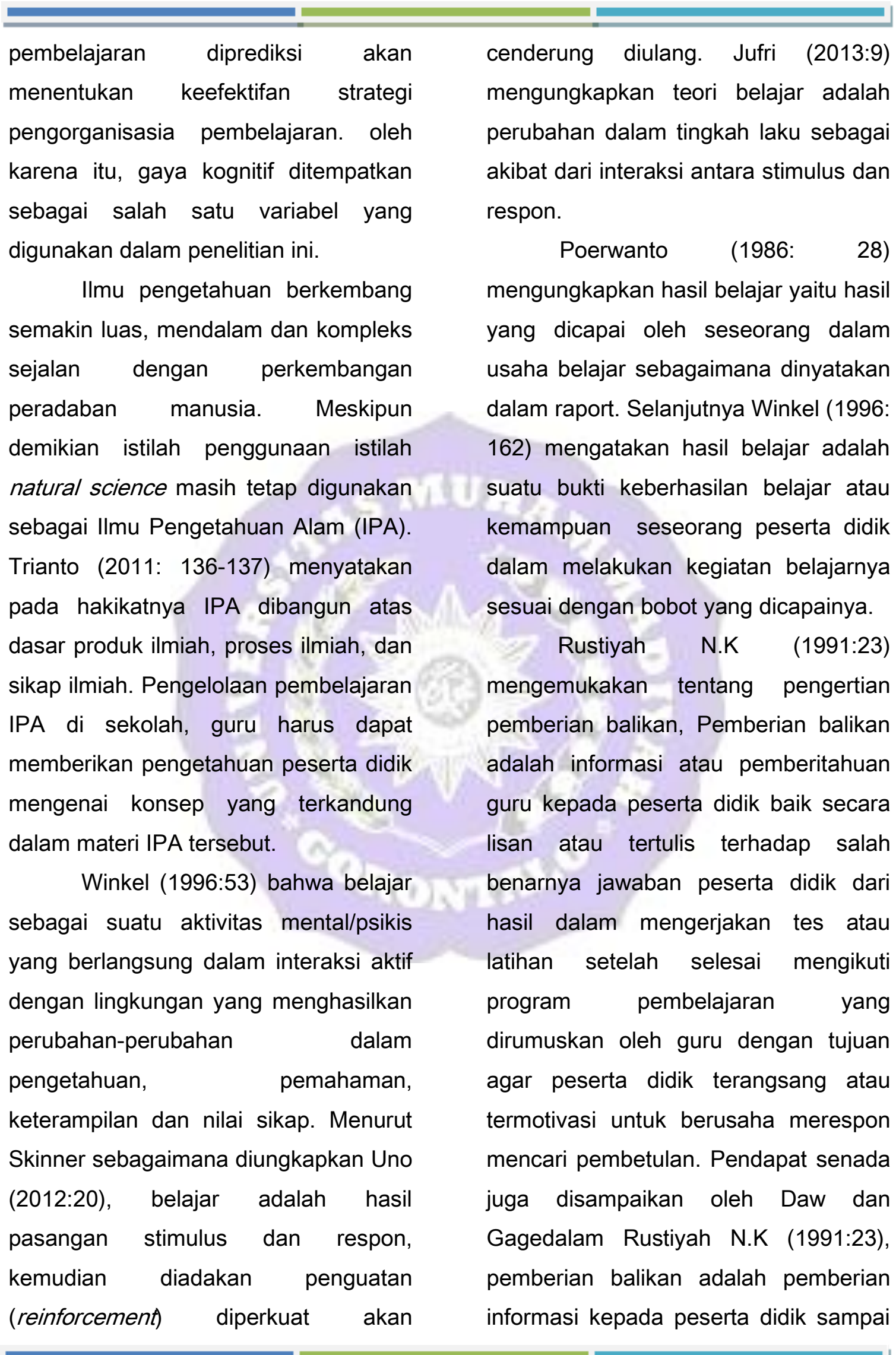


sejauh mana ia telah mencapai tujuan pembelajaran yang telah dirumuskan. Kim Ji Hyun (2013), memberi definisi pemberian balikan adalah suatu komunikasi antara guru dan peserta didik dalam hal memudahkan peserta didik memperbaiki kekurangannya dalam proses pembelajaran.

Kiram (1993:141), pemberian balikan merupakan pemberian koreksi terhadap unjuk kerja yang ditampilkan anak didik. Selanjutnya maksud pemberian balikan adalah bahwa pemberian balikan dapat mempercepat penguasaan suatu keterampilan dan tanpa pemberian balikan akan memperlambat proses pencapaian hasil yang optimal.

Menurut Keefe (1987:7), gaya kognitif merupakan bagian dari gaya belajar yang mengambarkan kebiasaan berprilaku yang tetap dalam diri seseorang dalam menerima, memikirkan, memecahkan masalah maupun menyimpan informasi. Ausburn (Uno, 2012 :186) gaya kognitif mengacu pada proses kognitif seseorang yang berhubungan dengan pemahaman, pengetahuan, persepsi, pikiran, imajinasi dan pemecahan masalah.

Witkin (Uno, 2012 : 186). mengemukakan bahwa gaya kognitif sebagai ciri khas peserta didik dalam belajar Sedangkan Messich, mengemukakan bahwa gaya kognitif merupakan kebiasaan seseorang dalam memproses informasi. Sementara Keefe mengemukakan bahwa gaya kognitif merupakan bagian dari gaya belajar yang mengambarkan kebiasaan berprilaku yang relatif tetap dalam diri seseorang dalam menerima, memikirkan, memecahkan masalah maupun dalam menyimpan informasi (Uno, 2012 : 186).

\section{METODE PENELITIAN}

Penelitian ini dilaksanakan di SMP Negeri 2 Bongomeme salah satu sekolah menengah pertama yang terletak di Desa Duwanga Kecamatan Dungaliyo Kabupaten Gorontalo, mengunakan metode eksperimen desain factorial ANAVA2 $\times 2$. Variabel yang diteliti adalah teknik pemberian balikan sebagai variabel kondisi terhadap gaya kognitif. Teknik pemberian balikan (A) terdiri dari teknik pemberian balikan langsung $\left(A_{1}\right)$ dan teknik pemberian balikan tertunda $\left(\mathrm{A}_{2}\right)$, sedangkan gaya kognitif spasial tinggi $\left(B_{1}\right)$ dan gaya kognitif spasial rendah $\left(B_{2}\right)$. 


\section{Pengumpulan Data}

Data yang dikumpulkan dalam penelitian adalah data tentang gaya kognitif dan data hasil belajar peserta didik. Pengumpulan data dilakukan dengan menggunakan dua macam instrumen meliputi (a) Instrumen untuk mengukur variabel atribut yaitu tes gaya kognitif, dan (b) instrumen untuk mengukur variabel terikat yaitu tes hasil belajar peserta didik.

Instrumen gaya kognitif menggunakan instrumen gaya kognitif yang baku (di adaptasi dari Uno (2014) yang sudah divaliditasi dan direliabilitas). Sedangkan tes hasil belajar disusun berdasarkan materi yang dibelajarkan pada materi tekanan sesuai dengan silabus IPA kelas VIII.

Analisis yang digunakan meliputi analisis deskriptif dan analisis infrensial. Analisis deskriptif dilakukan untuk menyajikan data setiap variabel dalam besaran-besaran statistik seperti ratarata (mean), nilai tengah (median), frekuwensi terbanyak (modus), simpangan baku (standar deviasi), dan menvisualisasikan ke dalam bentuk tabel distribusi frekuwensi dan histogram, sedangkan analisis infrensialmerupakan uji persyaratan analitis dan uji hipotesis berupa: (1) uji normalitas data, uji Liliefors (Sudjana,
2005:466), uji homogenitas varians, dengan uji Barlett (Sudjana, 2005: 261) dan uji Analisis of Varians (ANAVA) dua jalur untuk menguji hipotesis penelitian yang dilakukan dengan uji tuckey.

Dengan menggunakan harga rata-rata (mean) ditambah standar deviasi merupakan batas kelompok peserta didik yang mempunyai gaya kognitif spasial tinggi, dan harga ratarata (mean) dikurangi standar deviasi sebagai kelompok peserta didik yang mempunyai gaya kognitif spasial rendah. Adapun kelompok subyek yang mempunyai gaya kognitif spasial tinggi dan gaya kognitif spasial tinggi. Untuk menguji validas butir tes terbentuk data diskrit atau dikotomi yaitu benar diberi skor 1 dan salah diberi skor 0 menggunakan formula korelasi poin biserial yaitu korelasi antar skor butir tes dengan skor total tes, dan untuk menguji reliabilitas instrument menggunakan rumus $A / p h a$ Cronbach.

\section{HASIL PENELITIAN DAN PEMBAHASAN}

Data hasil belajar peserta didik pada mata pelajaran IPA di kelas VIII SMP Negeri 2 Bongomemedisajikan dalam delapan kelompok, (1) data hasil belajar IPA peserta didik yang dibelajarkan dengan teknik pemberian 
balikan langsung (Sel $A_{1}$ ); (2) data hasil belajar IPA peserta didik yang dibelajarkan dengan teknik pemberian balikan tertunda (Sel $A_{2}$ ); (3) data hasil belajar IPA peserta didik yang memiliki gaya kognitif spasial tinggi (Sel $\left.B_{1}\right)$; (4) data hasil belajar IPA peserta didik yang memiliki gaya kognitif spasial rendah(Sel $\left.\mathrm{B}_{2}\right)$; (5) data hasil belajar IPA peserta didik yang memiliki gaya kognitif spasial tinggi yang dibelajarkan dengan teknik pemberian balikan langsung (Sel $\left.A_{1} B_{1}\right) ;(6)$ data hasil belajar IPA peserta didik yang memiliki gaya kognitif spasial rendah yang dibelajarkan dengan teknik pemberian balikan langsung (Sel $\left.A_{1} B_{2}\right)$; (7) data hasil belajar IPA peserta didik yang memiliki gaya kognitif spasial tinggi yang dibelajarkan dengan teknik pemberian balikan tertunda (Sel $\left.A_{2} B_{1}\right)$;

(8) data hasil belajar IPA peserta didik yang memiliki gaya kognitif spasial rendah yang dibelajarkan dengan teknik pemberian balikan tertunda (Sel $\left.A_{2} B_{2}\right)$.

Hasil perhitungan dengan Uji Liliefors menunjukan bahwa kedelapan kelompok data tersebut memiliki tingkat normalitas data disajikan dalam Tabel 1 berikut ini :
Tabel 1. Hasil Uji Normalitas Data Hasil Belajar IPA padamasingmasingkelompok

\begin{tabular}{ccccc}
\hline Kelompok & $\mathrm{N}$ & $\mathrm{L}_{0}$ & $\mathrm{~L}_{\mathrm{t}(\alpha=0,01)}$ & Kesimpulan \\
\hline $\mathrm{A}_{1}$ & 28 & 0,1374 & 0,187 & Normal \\
$\mathrm{A}_{2}$ & 28 & 0,1586 & 0,187 & Normal \\
$\mathrm{B}_{1}$ & 28 & 0,1026 & 0,187 & Normal \\
$\mathrm{B}_{2}$ & 28 & 0,1483 & 0,187 & Normal \\
$\mathrm{A}_{1} \mathrm{~B}_{1}$ & 14 & 0,1230 & 0,261 & Normal \\
$\mathrm{A}_{1} \mathrm{~B}_{2}$ & 14 & 0,1271 & 0,261 & Normal \\
$\mathrm{A}_{2} \mathrm{~B}_{1}$ & 14 & 0,1566 & 0,261 & Normal \\
$\mathrm{A}_{2} \mathrm{~B}_{2}$ & 14 & 0,1909 & 0,261 & Normal \\
\hline
\end{tabular}

Dari Tabel 1di atas dapat diahami bahwa $L_{0}$ kedelapan Kelompok tersebut lebih kecil dari $L_{t}\left(L_{0}<L_{t}\right)$, ini berarti $\mathrm{H}_{0}$ diterima.Dengan demikian dapat disimpulkan bahwa sampel dari kedelapan kelompok di atas adalah berasal dari populasi yang berdistribusi normal.

Pengujian hipotesis ini dilakukan dengan teknik Analisis Varians 2 jalur (ANAVA $2 \times 2$ ), kemudian dilakukan uji lanjut dengan menggunakan uji tuckey. Analisis Varians dua jalur adalah suatu teknik perhitungan(statistik parametrik) yang bertujuan untuk menyelidiki dua pengaruh, yaitu pengaruh utama (main effect) dan pengaruh interaksi (interaction effect). 
Adapun hasil perhitungan ANAVA 2 jalur ini secara ringkas dapat di lihat pada Tabel 3.

ANAVA di atas, dapat dijelaskan:

1) Hasil analisis varians dua jalur antar kolom diperoleh harga $F_{\text {hitung }}=4,09$ lebih besar dari $F_{\text {tabel }}=4,03$ pada taraf signifikansi $\alpha=0,05$. Hasil perhitungan menunjukan skor ratarata hasil belajar IPA pada peserta yang dibelajarkan dengan teknik pemberian balikan langsung $\left(A_{1}\right)$ sebesar 16,86 lebih tinggi dari skor rata hasil belajar IPA pada peserta didik yang dibelajarkan dengan teknik pemberian balikan tertunda $\left(A_{2}\right)$ sebesar 15,68 dengan demikian hipotesis pertama yang menyatakan, secara keseluruhan hasil belajar IPA pada peserta didik yang dibelajarkan dengan teknik pemberian balikan langsung lebih tinggi dari hasil belajar IPA pada peserta didik yang dibelajarkan dengan teknik pemberian balikan tertunda.

2) Hasil analisis varians dua jalur antara kolom dan baris diperoleh harga $F_{\text {hitung }}=17,86$ lebih besar dari $F_{\text {tabel }}=7,17$ pada taraf signifikansi $\alpha$ $=0,01$. Dengan demikian hipotesis alternatif yang menyatakan terdapat interaksi antara teknik pemberian balikan dan gaya kognitif terhadap hasil belajar IPA diterima secara signifikan.

Hasil perhitungan uji lanjut dengan uji tuckeyuntuk kedua kelompok/subyek yang dibandingkan tersebut disajikan pada tabel berikut.

Tabel 3. Rangkuman Hasil Perhitungan ANAVA Data Hasil Belajar IPA

\begin{tabular}{|c|c|c|c|c|c|c|}
\hline SumberVariansi & $\begin{array}{c}\text { JumlahKuadrat } \\
\qquad(\mathrm{JK})\end{array}$ & dk & $\begin{array}{c}\text { Rata- } \\
\text { rata } \\
\text { Kuadrat } \\
\text { ( RK) }\end{array}$ & $\boldsymbol{F}_{\text {hitung }}$ & $\begin{array}{c}\mathbf{F}_{\text {tabel }} \\
(\alpha= \\
0,05)\end{array}$ & $\begin{array}{c}F_{\text {tabel }} \\
(\alpha= \\
0,01)\end{array}$ \\
\hline AntarKolom & 19,45 & 1 & 19,45 & $4,09^{*}$ & 4,03 & 7,17 \\
\hline AntarBaris & 123,02 & 1 & 123,02 & $25,85^{* *}$ & 4,03 & 7,17 \\
\hline InteraksiKolom\&Baris & 85,02 & 1 & 85,02 & $17,86^{* *}$ & 4,03 & 7,17 \\
\hline KekeliruandalamKelompok(d) & 247,50 & 52 & 4,76 & - & - & - \\
\hline Total & 474,98 & 55 & 232,24 & - & - & - \\
\hline \multicolumn{6}{|c|}{ Keterangan : * $=$ signifikan pada $\alpha=0,05$} & \\
\hline
\end{tabular}


Tabel 4. Ringkasan Hasil perhitungan Uji Tuckey $(\alpha=0,05)$

\begin{tabular}{ccccc}
$\begin{array}{c}\text { Kelompok } \\
\text { Perbandingan }\end{array}$ & $Q_{\text {hitung }}$ & $\begin{array}{c}Q_{\text {tabel }} \\
(0,05)\end{array}$ & $\begin{array}{c}Q_{\text {tabel }} \\
(0,01)\end{array}$ & Kesimpulan \\
\hline $\begin{array}{c}\mathrm{A}_{1} \mathrm{~B}_{1} \text { dengan } \\
\mathrm{A}_{2} \mathrm{~B}_{1}\end{array}$ & 6,25 & 3,03 & 4,21 & Signifikan \\
$\mathrm{A}_{1} \mathrm{~B}_{2}$ dengan & & & & \\
$\mathrm{A}_{2} \mathrm{~B}_{2}$ & 3,12 & 3,03 & 4,21 & Signifikan \\
\hline
\end{tabular}

Dari hasil perhitungan uji tuckey di atas, maka dapat ditarik kesimpulan sebagai berikut:

1) Hasil analisis dengan uji tuckey untuk kelompok siswa $\left(A_{1} B_{1}\right)$ yang memiliki gaya kognitif spasial tinggi menunjukan, bahwa teknik pemberian balikan langsung memberikan pengaruh yang lebih baik terhadap hasil belajar IPA dibandingkan dengan teknik pemberian balikan tertunda. Harga $Q_{\text {hitung }}=6,25>Q_{\text {tabel }}=3,03$ $(\alpha=0,05)$. Juga nilai rata-rata hasil belajar dari kelompok $\mathrm{A}_{1} \mathrm{~B}_{1}(X=$ 19,57) lebih tinggi dari kelompok $\mathrm{A}_{2} \mathrm{~B}_{1}(X=15,93)$. Artinya, hipotesis ini diterima atau teruji secara signifikan.

2) Hasil analisis dari uji tuckeyuntuk kelompok siswa $\left(\mathrm{A}_{2} \mathrm{~B}_{2}\right)$ yang memiliki gaya kognitif spasial rendah menunjuka, bahwa teknik pemberian balikan tertunda memberikan pengaruh yang lebih baik terhadap hasil belajar IPA dibandingkan dengan teknik pemberian balikan langsung $\left(A_{1} B_{2}\right)$. Harga $Q_{\text {hitung }}=3,12>Q_{\text {tabel }}=$ $3,03(\alpha=0,05)$. Juga nilai rata-rata hasil belajar dari kelompok $\mathrm{A}_{2} \mathrm{~B}_{2}(X$ $=14,14)$ lebih tinggi dari kelompok $A_{1} B_{2}(X=15,88)$. Artinya, hipotesis ini diterima atau diterima secara signifikan.

Hasil belajar peserta didik yang dibelajarkan dengan teknik pemberian balikan langsung lebih tinggi daripada hasil belajar peserta didik yang dibelajarkan dengan teknik pemberian balikan tertunda.

Berdasarkan hasil analisis data, perbedaan hasil belajar IPA yang dibelajarkan dengan teknik pemberian balikan langsung dan teknik pemberian balikan tertunda. hal ini menunjukan koefisien ANAVA (F) sebesar 4,09 yang ternyata signifikan.

Teknik pemberian balikan langsung menunjukan penerimaan informasi kepada peserta didik sebagai penerima pasif informasi menjadi pengkonstruksi aktif dalam proses pembelajaran. Pengerjaan latihan yang 


$\begin{array}{lll}\text { dilaksanakan oleh peserta didik } & \text { bisa diselesaikan dengan pemberian } \\ \text { langsung dipantu oleh guru sehingga } & \text { balikan langsung yang dapat } \\ \text { guru dapat memberikan balikan secara } & \text { meningkatkan memori, sehingga } \\ \text { langsung apabila terdapat kekeliruan } & \text { pemberian balikan langsung lebih baik } \\ \text { peserta didik dalam menyelesaikan } & \text { daripada pengolahan memori dengan } \\ \text { permasalahan. Pemberian balikan } & \text { menggunakan pemberian balikan } \\ \text { tertunda berupa pemberian tugas yang } & \text { tertunda }\end{array}$

dikerjakan diluar jam pembelajaran.

pemberian balikan tertunda memiliki

tujuan agar peserta didik memperoleh hasil belajar yang lebih baik, karena siswa dapat melaksanakan latihan selama melakukan tugas. pemberian balikan tertunda dilaksanakan dengan memberikan balikan kepada peserta didik untuk dikerjakan di rumah dengan mempertanggung jawabkan hasil pekerjaannya kepada guru.

\section{Pengaruh interaksi antara teknik pemberian balikan dan gaya kognitif terhadap hasil belajar IPA}

Hasil uji hipotesis ini menunjukan adanya pengaruh interaksi antara teknik pemberian balikan dengan gaya kognitif peserta didik dalam mempengaruhi hasil belajar IPA menjadi konsepsi ilmiah. Hal ini ditegaskan dalam pengujian hipotesis dengan $F_{\text {hitung }} 17,86$ sedangkan $F_{\text {tabel }}$ Teknik pemberian balikan ini dimaksudkan untuk memberikan evaluasi terhadap mata pelajaran yang telah dipelajari serta memberikan informasi berupa koreksi terhadap unjuk kerja yang ditampilkan peserta didik. Suatu aktivitas belajar dengan pemberian balikan langsung akan meningkatkan ingatan jangka pendek menuju ingatan yang lebih tetap (permanen). Sebagaimana diungkapkan oleh Metcalfe, Kornell and Finn (2009: 1078) mengatakan bahwa pengolahan kesulitan pembelajaran pada $\alpha=0,01$ yang sebesar 7,17. Dengan demikian kriteria yang ada berarti terdapat pengaruhinteraksi antara teknik pemberian balikan dan gaya kognitif terhadap hasil belajar IPA.

Peserta didik dengan gaya kognitif spasial tinggi cenderung dapat menganalisis dan memahami terhadap informasi yang dipelajari dengan baik apabila proses penyelesain latihan soal diberikan dengan pemberian balikan langsung. Peserta didik yang memiliki gaya kognitif spasial tinggi lebih tepat menggunakan pembelajaran dengan 
pemberian balikan langsung.Peserta didik dengan gaya kognitif spasial rendah cenderung dapat menganalisis dan memahami terhadap informasi yang dipelajari dengan baik apabila proses penyelesain latihan soal diberikan dengan pemberian balikan tertunda. Disamping itu, mereka dapat mengembangkan struktur materi pembelajaran yang disajikan dan mampu memecahkan masalah dengan bimbingan. Peserta didik yang memiliki gaya kognitif spasial rendah lebih tepat menggunakan pembelajaran dengan pemberian balikan tertunda.

Pada kelompokpeserta didik yang memiliki gaya kognitif spasialtinggi, hasilbelajar IPA pesertadidikyang dibelajarkan dengan teknik pemberian balikan langsung lebih tinggi daripada peserta didik yang dibelajarkan dengan teknik pemberian balikan tertunda

Hasil belajar IPA yang memiliki gaya kognitif spasial tinggi dengan dibelajarkan dengan teknik pemberian balikan langsung memiliki skor rata-rata 19,57 lebih tinggi dari pada hasil belajara IPA pada peserta didik yang dibelajarkan dengan teknik pemberian balika tertunda dengan skor rata-rata 15,93 dalam perhitungan lanjutan dengan Uji tuckey(Q) diperoleh $Q_{\text {hitung }}$ Sebesar 6,25 yang ternyata signifikas jika dibandingkan dengan harga $Q_{\text {tabel }}$ yang sebesar 3,03

Peserta didik yang dibelajarkan dengan teknik peberian balikan langsung hasil belajarnya lebih tinggi daripada peserta didik yang dibelajarkan dengan teknik pemberian tertunda hal ini disebabkan karena peserta didik yang menyelesaian latihan soal secara langsung diberikan masukan atau penguatan informasi oleh guru tentang pengerjaan soal yang dikerjakan sesuai dengan jawaban yang diharapkan serta bimbingan terhadap langkah-langkah pengerjaan soal latihan yang dikerjakan dengan waktu yang singkat.

Peserta didik yang memiliki gaya kognitif spasial tinggi proses pembelajaran dengan menggunakan teknik pemberian balikan langsung sangat tepat dibandingkan proses pembelajaran dengan teknik pemberian balikan tertunda untuk diterapkan pada peserta didik yang memiliki gaya kognitif spasial tinggi. Hasil penelitian ini dapat diasumsikan bahwa peserta didik dengan gaya kognitif spasial tinggi mampu memahami dan menguasai materi dari latihan yang dilaksanakan. 
Dengan kata lain gaya kognitif spasial tinggi dan diajarkan dengan teknik pemberian balikan langsung dapat memudahkan peserta didik dalam menguasai, memahami, menganalisis, keterampilan.

Pada kelompok peserta didik yang memiliki gaya kognitif spasialrendah, hasilbelajar IPA peserta didik yang dibelajarkandengan teknik pemberian balikan langsung lebih rendah daripada peserta didik yang dibelajarkan dengan teknik pemberian balikan tertunda

Dari hasil analisis data, diduga bahwa terdapat perbedaan hasil belajar IPA yang memiliki gaya kognitif spasial rendah dengan mengikuti pembelajaran dengan teknik pemberian balikan langsung dan teknik pemberian balikan tertunda. hasil yang menunjukan angka pada uji tuckey (Q) sebesar 3,12jika dibandingkan dengan harga $Q_{\text {tabel }}$ yang sebesar 3,03 yang ternyata signifikan. Dari hasil uji tuckey ini menunuukan hasil belajar IPA yang memiliki gaya kognitif spasial rendah dengan teknik pemberian balikan tertunda memiliki skor rata-rata 15,43 ternyata lebih tinggi dari teknik pemberian balikan langsung yang memiliki skor rata-rata 14,14

Teknik pemberian balikan tertunda berpengaruh positif terhadap hasil belajar IPA untuk peserta didik yang memiliki gaya kognitif spasial rendah. Peserta didik yang dibelajarkan pemberian balikan tertunda lebih unggul daripada peserta didik yang dibelajarkan pemberian balikan langsung.Hal ini disebabkan karena pembelajaran dengan pemberian balikan tertunda ini memberikan keuntungan kepada peserta didik untuk berfikir tentang kesalahan dan bagaimana memperbaiki kesalahan tersebut akan tetapi pemberian balikan tertunda ini jangan diberikan selang waktu terlalu lama diberikan dengan apabila lama maka peserta didik lupa terhadap kesalahan.

Hasil belajar IPA yang memiliki gaya kognitif spasial rendah ini dapat dipengaruhi dengan teknik pemberian balikan tertunda karena peserta didik membutuhkan waktu yang lebih lama untuk menganalisis, keterampilan mengenal dan memecahkan masalah, keterampilan menyimpulkan, menguasai dan menyelesaikan latihan yang diberikan oleh guru. Penyelesaian dan bimbingan yang lebih lama akan memberikan hasil yang positif untuk meningkatkan hasil belajar IPA. Sehingga dikatakan peserta didik yang 
memiliki gaya kognitif spasial rendah dibelajarkan dengan teknik pemberian balikan tertunda akan memberikan hasil yang lebih efektif dari pada peserta didik yang dibelajarkan dengan teknik pemberian balikan langsung

\section{PENUTUP}

\section{Simpulan}

Berdasarkan temuan dan pembahasan hasil penelitian, maka dapat disimpulkan hal-hal sebagai berikut:

1. Secara keseluruhan hasil belajar IPA pada peserta didik yang dibelajarkan dengan teknik pemberian balikan langsung lebih tinggi dari hasil belajar IPA pada peserta didik yang dibelajarkan dengan teknik pemberian balikan tertunda.

2. Terdapat pengaruh interaksi antara teknik pemberian balikan dan gaya kognitif peserta didik terhadap hasil belajar IPA.

3. Pada kelompok peserta didik yang memiliki gaya kognitif spasial tinggi, hasil belajar IPA pada peserta didik yang dibelajarkan dengan teknik pemberian balikan langsung lebih tinggi daripada peserta didik yang dibelajarkan dengan teknik pemberian balikan tertunda.

4. Padakelompokpeserta didik yang memiliki gaya kognitif spasial rendah, hasil belajar IPA pada peserta didik yang dibelajarkandengan teknik pemberian balikan langsung lebih rendah daripada peserta didik yang dibelajarkan dengan teknik pemberian balikan tertunda.

\section{Saran}

Berdasarkan kesimpulan dan implikasi yang dikemukakan diatas, peneliti menyarankan beberapa hal sebagai berikut:

Pertama, sebagai pekerja profesional guru perlu merancang, mengembangkan, mengelola proses pembelajaran yang bervariatif yang disesuaikan dengan karakteristik peserta didik dan meteri pelajaran yang disajikan agar dapat menjangkau proses pembelajaran yang diterapkan yaitu teknik pemberian balikan langsung dan teknik pemberian balikan tertunda.

Kedua, guru perlu mengelompokkan peserta didik sesuai dengan gaya kognitif, merancang, mengembangkan dan mengelola pembelajaran sesuai karakteristik peserta didik tersebut.

Ketiga, guru perlu mengembangkan model pembelajaran dan 


\begin{abstract}
memperhatikan teknik pemberian sehingga peserta didik dapat termotivasi dalam mengikuti pembelajaran, sebab peserta didik yang memiliki motivasi belajar yang tinggi cenderung menunjukan hasil belajar yang maksimal.
\end{abstract}

\section{DAFTAR PUSTAKA}

Jufri H.A Wahab. 2013, Belajar dan Pembelajaran SAINS. Bandung : Reka Cipta.

Keefe, Jame W. 1987. Learning Style Theory And Practice. Virginia. Reston , Va: National Association of Secondery School Principals (NASSP)

KiramYanuar. 1993. BelajarMotorik. Jakarta :Depdikbud.

Kim Ji Hyun. 2013. Learner Understanding of Written Corrective Feedback and Its Relationship with Immediate Uptake and Retention in EFL Classrooms. Keimyung University Metcalfe Janet,dkk.2009. Delayed versus immediate feedback in children's and adults' vocabulary learning. Columbia University, New York, New York.

Musnandar. 2006. Keefektifan
Pengajaran Melalui Pengaruh Interaktif Antara Pemberian Balikan Dan Motivasi Berprestasi Terhadap Perolehan Belajar.

Purwanto M. Ngalim. 1986. Evaluasi Hasil Belajar. Yogyakarta : Pustaka Pelajar

Rustiyah, N.K. 1991. Strategi Belajar Mengajar. Jakarta: Bina Aksara.

Sudjana. 2005. Metode statistik. Bandung: Tarsito

Trianto. 2010. Model Pembelajaran Terpadu. Jakarta : Bumi Aksara.

Uno B. Hamzah. 2012. Orientasi Baru Dalam Psikologi Pembelajaran. Jakarta : Bumi Aksara.

2014. Variabel Penelitian dalam Pendidikan dan Pembelajaran. Jakarta : PT Ina Publikatama

Winkel, WS. 1996. Psikologi Pengajaran. Jakarta : Bumi Aksara 